\title{
IMPLEMENTATION OF THE RIGHT TO PRIVACY IN THE Lithuanian Law ON PATIENTS' Rights
}

\author{
JELENA KUTKAUSKIENË*
}

\section{INTRODUCTION}

The principle of privacy is considered to be a vital part of legal systems in democratic countries ${ }^{1}$. The principle of privacy is consistently established in international documents regulating civil and political rights, such as the 1948 Universal Declaration of Human Rights (Art. 12), the 1950 European Convention on Human Rights (Art. 8 Para. 1) and in other special documents governing patients' rights ${ }^{2}$. In Lithuanian constitutional doctrine it is acknowledged that a person's privacy is inviolable ${ }^{3}$. Furthermore, as a person's physical and mental state is considered to constitute part of a person's private life ${ }^{4}$, a person's right to privacy is protected by instruments of both civil and administrative law.

\section{SCOPE OF PATIENTS' CONFIDENTIAL INFORMATION AND its Legal Protection}

Article 2.23 Para. 2 of the Civil Code of the Republic of Lithuania (hereinafter - Civil Code) explicitly names publishing information about a person's health as one possible breach of privacy. However, sources of health law define the scope of a patient's confidential information and the conditions in which such information may be recorded, stored and revealed. Article 8 Para. 3 of the Law on the Rights of Patients and Compensation for Damage to Their Health (hereinafter - Patients' Rights Law) defines

DOI: $10.1515 /$ wrlae-2015-0011

* PhD; Assistant Professor of Law Philosophy and Law History Department, Professor of Institute of Constitutional and Administrative Law; Mykolas Romeris University; jelena.kutkauskiene@karpol.lt.

${ }^{1}$ Jonas Juškevičius, Janina Balsienė, 'Human rights in healthcare: some remarks of the limits on the right to healthcare' (2010) 122 (4) Jurisprudence 95.

${ }^{2}$ Konvencija dèl žmogaus teisių ir orumo apsaugos biologijos ir medicinos taikymo srityje (Žmogaus teisių ir biomedicinos konvencija) [2002] OJ 97-4258; WHO Regional Office for Europe, Declaration on the promotion of patients rights in Europe (Copenhagen 1994), $<$ http://www.who.int/genomics/public/eu declaration1994.pdf $>$ accessed 10 October 2013.

3 Lietuvos Respublikos Konstitucija [1992] OJ 33-1014; [2006] OJ 48-1701.

${ }^{4}$ Lietuvos Respublikos Konstitucinio Teismo 2003 m. kovo 24 d. nutarimas Nr 3/01 „Dèl nuteistujų korespondencijos cenzūros“ [2003] OJ 29-1196. 
patients' confidential information as all information concerning the condition of a patient's health, including diagnosis, prognosis and treatment as well as all other information of a personal nature concerning the patient. Since the aforementioned law does not provide us with a numerus clausus list of what is considered personal information, it is unclear what other confidential information may be legally collected and stored when providing healthcare services. It is worth noting that in constitutional doctrine the sphere of privacy is exceptionally wide. A person's lifestyle, family status, living environment, relations with other people, views, believes and habits, physical and mental state, honour, dignity, etc., are all considered to constitute part of a person's private life ${ }^{5}$. Therefore, when defining what other private information may be collected when providing healthcare services, particular attention must be drawn to the aim of collecting and storing such information - e.g. illness diagnosis, treatment and patient nursing ${ }^{6}$. Despite the fact that the explanatory report of the Convention on Human Rights and Biomedicine suggests that doctors ought to address the personal traits of every patient, this creates ethical problems if a doctor takes an interest in a patient's social and cultural interests, such as his professional activities, interests and leisure activities without invading his privacy. The Supreme Court of Spain stated that a doctor, having failed to find out that his patient is a professional performer (in that case - a pianist) and that maintaining the agility of the fingers is of tremendous importance to the patient, caused the patient harm when he chose to perform an operation which involved a lesser risk than the alternative but resulted in a decline in finger agility ${ }^{7}$. On the other hand, a patient who does not have any special medical knowledge obviously may not know what personal information may be important for illness diagnosis and nursing. Therefore, the possibility of collecting other personal information does rely on an uncertain assumption regarding patients' abilities to properly understand the relation between their state of health and details of their private life ${ }^{8}$.

Furthermore, it is necessary to take into consideration the fact that the collection of a patient's personal data comprises two stages. Firstly, it involves actions that undertaken by a doctor when gathering information about the patient's symptoms, including the time frame and causes thereof. Secondly, it comprises the recording of the patient's personal information in medical documents. Naturally, medical documents contain information only relevant to diagnostics, treatment or nursing, which stem from not only from data the provided by the patient but also from objective-analysis data, the diagnosis, prescribed treatment, etc. Nevertheless, the obligation of confidence for the healthcare specialist remains, not only during the process of treatment but also after it when processing statistical or archive medical

\footnotetext{
${ }^{5}$ Lietuvos Respublikos Konstitucinio Teismo 2002 m. rugsèjo mèn. 19 d. nutarimas „Dèl Telekomunikacijų, Operatyvinès veiklos įstatymų ir Baudžiamojo proceso kodekso“ [2002] OJ 93-4000.

${ }^{6}$ Lietuvos Respublikos pacientų teisių ir žalos sveikatai atlyginimo ístatymas [2009] OJ 145-6425 (The Rights of Patients and Compensation for the Damage to Their Health Act hereinafter Patients' Rights Law) art 8 para 1.

${ }^{7}$ Michael Faure, Helmut Koziol (eds), Cases on Medical Malpractice in a Comparative Perspective (Springer - Verlag 2001) 187-195.

${ }^{8}$ Marchall Kapp, 'Patient Autonomy in the Age of Consumer-Driven Health Care: Informed Consent and Informed Choice’ (2007) 91 Journal of Legal Medicine 91.
} 
documentation $^{9}$, with exceptions provided for by law ${ }^{10}$. Article 6.733 of the Civil Code establishes the obligation of healthcare providers to collect and store patient medical documents. However, the list of mandatory documents to fill out was endorsed more than a decade ago ${ }^{11}$ and does not relect the level of current technologies and e-health systems.

A separate analysis is required for the legal regime of patient confidential information protection, which are established by the Law on the Legal Protection of Personal Data (hereinafter - Personal Data Law). Data regarding patients' health is considered to be a special category of personal data (Art. 2 Para. 8 of the Personal Data Law ${ }^{12}$ ). The year 2002 version of Art. 10 of the Personal Data Law defined what constituted health-related personal data. It covered data about a person's health state, diagnosis, prognosis and treatment. However, the current version of the Personal Data Law does not include such a list. This means that "other" information needed to diagnose, treat an illness or to nurse a patient may also be regarded as data on a person's health, which therefore means a de facto expansion of the concept of data about a person's health. If the basis of collection and storage of other special categories of personal data (for instance, information on a person's political, religious views or sex life) were to be associated with the basic interests of the data subject, the protection of personal data is achieved by setting a particular category of data processor - in this case, a person employed in the healthcare system ${ }^{13}$. This category is wider than the category of people that provide healthcare services, and their right to engage in professional activities is regulated by legal acts ${ }^{14}$ and ought to be associated not with their qualification, as is stated in the commentary of the Personal Data Law, but with the presence of relationship of labour law. In practice, medical receptionists and medical statisticians take part the processing personal data and they are included in the category of healthcare workers. All of the above-mentioned personnel are obliged to protect patients' confidential information ${ }^{15}$.

\footnotetext{
${ }^{9}$ LR sveikatos apsaugos ministro 1999 m. gruodžio 16 d. ịsakymo Nr. 552 „Dèl Asmens sveikatos paslapties kriterijų patvirtinimo“" [1999] OJ109-3195.

${ }^{10}$ Lietuvos Respublikos sveikatos sistemos įstatymo (hereinafter - Health System Law) 52 str. 3 d. (art 52 para 3) [1994] OJ 63-1231; [1998] OJ 112-3099; Patients' Rights Law, art 9.

${ }^{11}$ LR sveikatos apsaugos ministro 1999 m. lapkričio 29 d. įsakymas Nr. 515 „Dèl sveikatos priežiūros įstaigų veiklos apskaitos ir atskaitomybès tvarkos“ [1999] OJ 103-2972; 105; LR sveikatos apsaugos ministro $1996 \mathrm{~m}$. birželio 13 d. ịsakymas Nr. 324 „Dèl medicininès apskaitos formu patvirtinimo“ [1996] OJ 57-1369); LR sveikatos apsaugos ministro 1996 m. gruodžio 31 d. ịsakymas Nr. 669 „Dèl apskaitos formų patvirtinimo“ [1997] OJ 4-61.

${ }^{12}$ Lietuvos Respublikos asmens duomenų teisinès apsaugos įstatymas [1996] OJ 63-1479; [2000] OJ 64-1924; [2003] OJ 15-597; [2008] OJ22-804.

${ }^{13}$ Asmens duomenu teisinès apsaugos ìstatymo komentaras. Valstybine duomenu apsaugos inspekcija, $<$ http://www.ada.lt/images/cms/File/komentaras\%20adtai.pdf $>>$ accessed 23 September 2013.

${ }^{14}$ Health System Law, art 50; Lietuvos Respublikos gydytojo medicinos praktikos įstatymas (Lietuvos Respublikos medicinos praktikos įstatymas) [1996] OJ 102-2313; [2004] 682365; Lietuvos Respublikos slaugos praktikos istatymas (Lietuvos Respublikos slaugos praktikos ir akušerijos praktikos įstatymas [2001] OJ 62-2224; [2009] OJ 89-3801; LR sveikatos apsaugos ministro $2007 \mathrm{~m}$. sausio 22 d. ịsakymas Nr. V-27 „Dèl Masažuotojo profesijos kvalifikacinių reikalavimų aprašo patvirtinimo“ [2007] OJ 11-452.

${ }^{15}$ „Dèl Asmens sveikatos paslapties kriterijų patvirtinimo“ (n 9).
} 
Patients' Rights Law establishes a protection mechanism of a patient's private life during the provision of healthcare services - a patient's consent for the collection of confidential information is mandatory ${ }^{16}$. However, the option for the patient to refuse to give such consent regarding information that is obviously needed to achieve the patient's goal, i.e. receiving quality healthcare services, clearly clashes with the patient's obligation to cooperate with healthcare specialists ${ }^{17}$.

As in many other countries (with the exception of France ${ }^{18}$ ), the Lithuanian legal system does not treat the inviolability of a patient's private life as an absolute right ${ }^{19}$. Even though it may seem that its personal nature would allow for a patient to freely disseminate information gathered in the course of treatment or nursing, the ability of a patient to spread such information is impeded. The requirement to share the patient's information only with specifically appointed people is to be regarded as a means of protecting a patient's interests. Not only does the law require such consent to be given in written form, but specific content requirements have also set. If a patient's request to reveal his information is a one-off occurrence (for instance, a request to reveal his personal information to his advocate), there ought to be grounds for such a disclosure (for instance, an agreement of representation) and a purpose for using the information (for instance, preparing a claim). If there are multiple requests for a patient's personal information to be disclosed (for instance, a request to disclose personal information to a spouse or children), it is mandatory for the patient to define the scope and term of provision of personal data in writing in medical documents. In other words, a patient may choose, if he wishes for all of his personal information to be available to the specified recipients or only a certain part of it, for instance information related to essential events hospitalisation, confirmed diagnosis, nomenclature of services provided (general practitioner, cardiologist, etc.). Furthermore, a patient may oblige the healthcare institution to provide particular information to specified recipients within a term set forth in the written consent.

Laws set forth an obligation for a healthcare specialist to make sure that when a patient gives his consent to disclosure personal information, the patient actually understands the action and consequences that may follow ${ }^{20}$. This presupposes that the healthcare specialist ought to not only de facto evaluate patients' civil capacity, which may be attributed to a specialist's competence, but also to foresee the possible outcome of information disclosure, i.e. future events. However, the above-mentioned exaggerated requirement of a patient's personal data protection may not be treated regarded as a impossibilium nulla obligatio est situation. The patient's right to revoke his consent or change the volume or recipients of the revealed information at any given time may be regarded as an additional means of

\footnotetext{
${ }^{16}$ Patients' Rights Law, art 8 para 1.

${ }^{17}$ Patients' Rights Law, art 12 para 2.

${ }^{18}$ Jean Martin, Oliver Guillod, 'The doctor's duty to maintain confidentiality ("medical secret") in Switzerland. What Attitude Should the Practitioner Adopt when Authorities or Outside People Ask for Information About a Patient?' (2001) 8 European Journal of Health Law 163.

${ }^{19}$ Lietuvos Aukščiausiojo Teismo Civilinių bylų skyriaus 2002 m. lapkričio mèn. 18 d. nutartis civilinèje byloje B. J. v. UAB ,,Valstiečiu laikraštis “ (bylos Nr. 3K-3-1373).

${ }^{20}$ „Dèl Asmens sveikatos paslapties kriterijų patvirtinimo“ (n 9).
} 
protecting the patient's confidential information ${ }^{21}$. In some other countries, for instance Switzerland, the disclosure of a patient's personal information on the basis of the patient's request is regulated not by establishing the patient's right to specify third parties to whom their information may be disclosed, but by the doctor's right to disclose the information to third parties on the patient's request. In some instances, if in the doctor's opinion the disclosure of the patient's personal information is inconsistent with the patient's interests, he may refuse to disclose such information. In such instances the patient may obtain extracts from his medical documents and disclose them to third parties himself $f^{22}$.

\section{Conditions of Limitation of a Patient's Right to PRIVACY}

As mentioned previously, a patient's right to a private life is not absolute and all its exemptions are based on the imperatives of protecting a patient's rights and prioritising a patient's interests. The principle of patient interests' priority may be regarded as an example of a significant change of legal concept and its application in particular stages of societal development. In pre-modern society the following of this principle was limited by the doctor-patient relationship. Today, in a post-modern society the principle is expanded to cover both patient-doctor and patient-society relationships. It must be noted that the current application of the principle of prioritising the patient's interests in the perspective of the relationship a healthcare specialist and a patient has not only declined, but has also significantly changed with the prevalence of principles of self-regulation and autonomy, which in a healthcare relationship essentially assert themselves in the healthcare practitioner's execution of the patient's informed consent indications ${ }^{23}$. Today legal doctrine reveals the principle of prioritising the patient's interests by exploring the ethical aspects of the patient-healthcare specialist relationship and by defining the possibilities and conditions of operation without the patient's informed consent. These conditions ${ }^{24}$ are transferred to documents establishing rules of professional behaviour. For instance, in 2008 the British Medical Council. having re-evaluated court precedents, updated its recommendations for doctors concerning cases where the doctor may expect that the disclosure of information is actually in the patients' best interest ${ }^{25}$. These recommendations were more than a decade old. In the perspective of the patient-society relationship two important aspects are distinguished. Firstly, the short-term best interest refers to that balance with respect to a specific healthcare decision, without

\footnotetext{
${ }^{21}$ Patients' Rights Law, art 8 para 4.

${ }^{22}$ Martin, Guillod (n 18).

${ }^{23}$ Tom Beauchamp, James Childress, Principles of biomedical ethics (Oxford University Press 2001); Jonas Juškevičius, 'Teisès principų taikymas norminant sveikatos priežiūros sritị’ (2008) 114 (12) Jurisprudencija 7.

${ }^{24}$ Health System Law, art 20 para 1.

25 General Medical Council, Seeking patients' consent: The ethical considerations, $<$ http://www.gmc-

uk.org/Seeking_patients_consent_The_ethical_considerations.pdf_25417085.pdf $>$ accessed 16 September 2013.
} 
reference to the overall situation. Scientists note the limit of the short-term perspective $^{26}$. The second aspect - the principle of prioritising the patient's interests in the long term - refers to the balance of benefits and burdens with respect to the ultimate goals or purposes of a community within which an individual is situated. Authors suggest that the limiting of the principle of prioritising the patient's interests over the interest of society is possible under these circumstances: (i) the application of the principle of prioritising the patient's interests is impossible, (ii) it is necessary to meet the needs of other individuals, (iii) the limitation is not based on unfair or unjust practices ${ }^{27}$. As these conditions for the limitation of principle of prioritising a patient's interests is formulated using general legal categories, it is necessary to conduct a special evaluation of whether the limitations set forth in the Lithuanian legal system are based on absolute necessity, align with the interests of society or are both legal and equitable.

Systematic analysis of sources of health law allows for a distinction of subjects that may receive a patient's confidential information without the patient's consent. Firstly, they must be people involved in the provision of healthcare services. This permission is based on the rule of proper professional activity, acknowledging that the difficulties of healthcare service provision (for instance, a difficult operation performed by a team of surgeons and assistants) or clinical situations (for instance, requiring a consilia) may lead to the disclosure of confidential information. When applying this exemption, additional protection of a patient's rights is ensured in certain methods. First of all, qualification requirements are set forth for team members to whom the information may be disclosed. Secondly, a specific circle of people who may obtain the patient's information is set - it covers only team members who take part in the provision of healthcare services. Thirdly, specialists who have obtained a patient's private information are burdened with the obligation of confidentiality. Forth, information may be provided only in such quantity that the protection of the patient's interests requires ${ }^{28}$.

Other subjects to whom a patient's confidential information may be disclosed to without his consent comprise parties to legal or social relationships whose existence depends upon knowledge of personal health data. This includes, for instance, contracts of insurance, granting licences or revoking them, granting social benefits etc. ${ }^{29}$. The second group of subjects who may obtain a patient's personal information without their consent is people who perform expert evaluations of a patient's health ${ }^{30}$. Usually when performing such a role certain questions of status are solved or evaluated, such as the patient's right to social grants. Health expertise may be performed not only by the doctor treating the patient but also by other institutions such as courts, offices of disability and capacity assessment and

\footnotetext{
${ }^{26}$ James Trau, Jane McCartney, 'In the best interest of the patient' (1993) 74 Health Progress 50.

${ }^{27}$ ibid.

${ }^{28}$ Leszek Bosek, Jakub Pawliczak, 'Codification of Patients' Rights in Poland - The Patients' Rights Act 2008' (2010) 17 European Journal of Health Law 361; Ilene Moore et al., 'Confidentiality and Privacy in Health Care from the Patient's Perspective: Does HIPPA Help' (2007) 17 Health Matrix 215.

${ }_{29}$ Asmens duomenu teisinès apsaugos istatymo komentaras (n 13).

${ }^{30}$ Health System Law, art 26-30.
} 
experts appointed by commission to perform periodical medical examinations. In these examples, the relationship between the doctor and expert are not fiduciary and the expert relies on knowledge of science and a thorough evaluation of all the relevant circumstances when providing the expertise report to the competent authority disregarding the obligation to protect a patient's private life. On the other hand, in relationships with third parties, the expert is obliged protect the patient's confidential information ${ }^{31}$.

Third group of subjects whom a patient's confidential information may be provided without the patient's consent is state institutions who are allowed to obtain such information by $\mathrm{law}^{32}$, when it is necessary in the interest of public safety, crime prevention, public health or for the protection of other persons' rights ${ }^{33}$. Confidential information may be provided when a healthcare specialist is exercising his duties, for instance informing the police about a gunshot or a stab wound or when the healthcare service provider is obliged to provide such information under the request of a competent state institution. The precedent in the case Tarasoff $v$. Regents of University of California ${ }^{34}$ has had an extraordinary influence on the US legal system. In this precedent, a doctor's duty to warn was set forth ${ }^{35}$. The court acknowledged that doctors and psychotherapists have a legal obligation to protect third parties from a foreseeable physical harm. The court stated that the privilege of protection ends where the danger to society occurs and the patient's inviolable right to a private life may be restricted if the patient is dangerous, except in cases when the patient may be controlled $^{36}$. Article 9 Para. 4 of the Patients' Rights Law obliges healthcare institutions to immediately inform law enforcement authorities about wounded patients, whose wounds may have been caused by criminal offences. This suggests that when executing this duty, a patient's private data may be disclosed based only on the assumption of such a fact. In other cases, i.e. when providing information following requests from competent institutions, supplementary means of legal protection are applied. It is required that the enquirer (i) states the goal of using the requested information (for instance, the data would be joined to and used in a criminal case), and (ii) reveal the legal grounds for such disclosure - a particular legal norm prohibiting obtaining of the data requested ${ }^{37}$, for instance Art. 97 of Penal Code of Lithuania.

A fourth group of subjects allowed to obtain information without the patient's consent are insurers of the healthcare service provider's civil liability. Insurers are may obtain a patient's confidential information only in

\footnotetext{
${ }^{31}$ Martin, Guillod (n 18).

${ }^{32}$ Lietuvos Respublikos sveikatos priežiūros ịstaigų įstatymo 13 str. 3 d [1996] OJ 66-1572; [1997] OJ 62-1462; [1998] OJ 109-2995; Patients' Rights Law, art 9 para 1.

${ }^{33}$ B. J. v. $U A B$ (n 19).

${ }^{34}$ Tarasoff $v$. Regents of University of California, 551 P. 2d. 334 (Cal.1976).

${ }^{35}$ Lisa Grossman, Gerald Koocher, 'Privacy Confidentiality, and Privilege of Health Records and Psychotherapy Notes in Custody Cases' (2010) 24 American Journal of Family Law 41.

${ }^{36}$ Rebecca Suarez, 'Breaching Doctor-Patient Confidentiality: Confusion among Physicians about Involuntary Disclosure of Genetic Information' (2011) 21 Southern California Interdisciplinary Law Journal 491.

${ }^{37}$ Valstybinès duomenų apsaugos inspekcijos 2011-01-31 nurodymas Nr. 2R-410-2.13 „Dèl asmens duomenų tvarkymo“.
} 
cases where a patient's claim regarding compensation for damage to his health is being evaluated ${ }^{38}$.

Confidential information may be provided to state institutions and insurers only upon written request, which must contain details of the basis for information disclosure, the goals of its usage and the scale of information needed. Disclosure of a patient's confidential information must comply with principles of reasonableness, equity, the protection of a patient's rights and the priority of the patient's interests ${ }^{39}$. It should be noted that Art. 9 Para. 3 of the Patients' Rights Law requires that when disclosing a patient's confidential information it is necessary to ensure that the patient's interests and well-being is more important than the interests of the public. However, this is not commensurate either with the numerus clausus list established in the second sentence of the same paragraph, or with Art. 22 of the Constitution and European Convention on Human Rights. The Constitutional Court held that the "right to protection of private life ends when a person brakes the public interest either by making criminal offences or in any other illegal way and causes harm to particular persons, the society or the state" 40 . Article 8 of the European Convention on Human Rights set forth a list of more concrete conditions under which the right to an inviolable private life may be restricted and the Parliament of Lithuania transferred these conditions to law by setting forth that a patient's right to a private life may be restricted "when it is necessary for the protection of public safety, public health other persons' rights and liberties or crime prevention" 41 .

The general rule of protection of a patient's private information sets forth that the doctor must not disclose it without the patient's consent or when no conditions for exceptions set forth in the laws are present. One such exception is related to the protection of the public from contagious diseases. Lithuania is no exception here as the Law on the Prevention and Control of Communicable Diseases in Humans safeguards the right to privacy of the infected people by establishing that information regarding their health can be provided only in cases established by law ${ }^{42}$. It must be noted that the mentioned law, unlike the Law on Patients' Rights, provides additional grounds for disclosing confidential information by declaring that not only laws but also legal norms of lower rank may set the conditions of information provision regarding patients that carry infectious diseases or are suspected of being infected. Furthermore, neither law sets forth the mentioned conditions on information provision and a special executive legal act provides a blanket form that data shall be provided in accordance with the Law on the Legal Protection of Personal Data and other laws on information provision ${ }^{43}$.

\footnotetext{
${ }^{38}$ Patients' Rights Law, art 23 para 8.

${ }^{39}$ Patients' Rights Law, art 9 para 1.

40"Dèl operatyvinès veiklos įstatymo kai kurių straipsnių" (n 5).

${ }^{41}$ Patients' Rights Law, art 9 para 3.

${ }^{42}$ Lietuvos Respublikos žmonių užkrečiamųų ligų profilaktikos ir kontrolès įstatymas (hereinafter - Law on the Prevention and Control of Communicable Diseases in Humans) 34 str. (art 34) [1996] OJ 104-2363; [2001] OJ 112-4069.

${ }^{43} \mathrm{LR}$ sveikatos apsaugos ministro $2008 \mathrm{~m}$. sausio $14 \mathrm{~d}$. įsakymas Nr. V-19 „Dèl Užkrečiamųjų ligų ir jų sukèlèjų valstybės informacinès sistemos ir Užkrečiamụjų ligų ir jų sukèlèjų valstybès informacinès sistemos duomenų saugos nuostatų patvirtinimo (Dèl
} 
The Law on the Prevention and Control of Communicable Diseases in Humans sets forth the right of third persons who have been in contact with the infected person to obtain information regarding the consequences of contact with the infected patient and their obligatory hospitalisation ${ }^{44}$. A list of dangerous and extremely dangerous contagious diseases may be found when analysing orders of the Minister of Health. Firstly, the order of May 14th, 2003, No. V-276 establishes a list of 14 diseases which are considered dangerous $^{45}$. Secondly, the order of June 13th, 2002, No. V-278 sets forth a list of 71 dangerous diseases and 6 extremely dangerous diseases ${ }^{46}$. This order also enlists the dangerous diseases set forth in the first order of the Minister of Health, but it is criticised for including some widespread diseases such as scabies (common among homeless people), rotavirus or enterovirus infections (common among children) which are classified under other dangerous bacterial intestinal diseases.

By limiting the person's right to an inviolable private life in the context of contagious diseases, a greater protection of third persons and society as a whole is expected. In Lithuanian legal regulations two key aspects may be identified. The first aspect, which does not present any ethical issues, is the doctor's obligation to inform competent authorities regarding contagious diseases ${ }^{47}$. This is to help ensure the public health and application of appropriate preventative measures ${ }^{48}$. The second aspect, which does present ethical problems, is the doctor's duty to warn, especially when it comes to sexually transmitted diseases. In the context of contagious diseases, the limited and pre-set conditions of information disclosure, clear identification of these conditions and legitimised doctor's actions of information provision (except in cases where the patient has expressly stated his wish not to receive such information) do not present any legal problems. Even though the proportionality and reasonableness of the measures do not raise any doubts, healthcare specialists question whether the aim of the patient's right to a private life is achieved, i.e. if the patient is willing to disclose all

Užkrečiamųjų ligų ir jų sukèlèjų valstybès informacinės sistemos nuostatų patvirtinimo)“ [2008] OJ 10-366.

${ }^{44}$ Law on the Prevention and Control of Communicable Diseases in Humans, art 35 para 2.

${ }^{45}$ LR sveikatos apsaugos ministro 2002 m. birželio 13 d. įsakymas Nr. 278 „Dèl Pavojingu ir ypač pavojingų užkrečiamųjų ligų, dèl kurių ligoniai, asmenys, ịtariami, kad serga pavojingomis ar ypač pavojingomis užkrečiamosiomis ligomis, asmenys, turèję sąlytị, ar šių ligų sukèlèjų nešiotojai turi būti hospitalizuojami, izoliuojami, tiriami ir (ar) gydomi privalomai, sąrašo patvirtinimo“" [2002] OJ 62-2527.

${ }^{46}$ LR sveikatos apsaugos ministro 2009 m. gegužès 27 d. įsakymas Nr. V-414 „Dèl pranešimų apie užkrečiamąsias ligas ir jų sukẻlèjus formų patvirtinimo“ [2009] OJ 682777; „Dèl Užkrečiamụjų ligų ir jų sukèlëjų valstybès informacinès sistemos ir Užkrečiamujų ligų ir jų sukèlèjų valstybès informacinès sistemos duomenų saugos nuostatų patvirtinimo (Dèl Užkrečiamųų ligų ir jų sukèlëjų valstybès informacinès sistemos nuostatų patvirtinimo)“ (n 43).

47 „Dèl pranešimų apie užkrečiamąsias ligas ir jų sukèlëjus formų patvirtinimo” (n 46); „Dèl Užkrečiamujjų ligų ir jų sukèlëjų valstybės informacinès sistemos ir Užkrečiamųjų ligų ir jų sukèlëjų valstybès informacinès sistemos duomenų saugos nuostatų patvirtinimo (Dèl Užkrečiamųjų ligų ir jų sukėlèjų valstybès informacinès sistemos nuostatų patvirtinimo)“ (n 43).

${ }^{48}$ The Prevention and Control of Communicable Diseases in Humans Act; Lietuvos Respublikos visuomenès sveikatos stebėsenos (monitoringo) įstatymas [2002] OJ 72-3022). 
information relevant to diagnose the disease ${ }^{49}$, and whether the disclosure of such information would not lead to even greater social stigma of the patient (for instance, in cases when a patient is HIV positive) ${ }^{50}$.

In legal literature a doctor's duty to warn is widely analysed by presenting the problems of information disclosure regarding the results of genetic research which show mutations of genes ${ }^{51}$ that are dangerous not only to the health of the patients, but also their families. Bearing in mind the progress of genealogy and the increasing social warranties regarding gene research that are available to the public ${ }^{52}$, arguments presented in foreign legal doctrine are also relevant in Lithuania. In certain countries the protection of gene information is afforded on the legislative level, for instance in the United States the Genetic Information Non-discrimination Act was enacted in $2008^{53}$. The act afforded genetic information special legal protection.

However, in cases of personal information disclosure where the information disclosed considers a patient carrying a contagious disease, the patient is regarded as a source of danger to public health and this is widely discussed in legal doctrine. In such cases, the goals of information disclosure differ as the patient does not pose any danger to the health of others, therefore the disclosure of patient's genetic information is only allowed when it would prevent significant damage to public health. Furthermore, a few ethically sensitive questions regarding the disclosure of genetic information remain. Firstly, the disclosure of genetic information is only permitted to blood-related family members. Consequently, this may reveal the fact of adoption to the children adopted ${ }^{54}$ or may allow them to trace their biological father in the event of a sperm donation ${ }^{55}$. The second

\footnotetext{
${ }^{49}$ Lawrence Gostin, Public health law: power, duty, restraint (Vol. 3) (Univ of California Press 2008) 295-297.

${ }^{50}$ Lynn Jansen, Lainie Ross, 'Patient confidentiality and the surrogate's right to know' (2000) 28 The Journal of Law, Medicine \& Ethics 137.

${ }^{51}$ Ruth Stirton, 'Insurance, Genetic Information and the Future of Industry Self-Regulation in the UK' (2012) 4 Law, Innovation and Technology 212; Trevor Woodage, 'Relative Futility: Limits to Genetic Privacy Protection Because of the Inability to Prevent Disclosure of Genetic Information by Relatives' (2010) 95 Minnesota Law Review 682; Michael Fay, 'Negligence and the Communication of Neonatal Genetic Information to the Parents' (2012) 20 Medical Law Review 604.

${ }^{52} \mathrm{LR}$ sveikatos apsaugos ministro $2005 \mathrm{~m}$. birželio 23 d. įsakymas Nr. V-522 „Dèl Žmogaus genetikos paslaugų, apmokamų iš Privalomojo sveikatos draudimo fondo biudžeto, sąrašo ir jų bazinių kainų patvirtinimo“" [2005] OJ 90-3380; LR sveikatos apsaugos ministro 2008 m. sausio 17 d. ịsakymas Nr. V-49 „Dèl Imunotipavimo, genetinio, kraujo krešejjimo veiksnių tyrimų, apmokamų iš Privalomojo sveikatos draudimo fondo biudžeto, atlikimo reikalavimų ir apmokejjimo sąlygų aprašo patvirtinimo“ [2008] OJ 12406.

53 Genetic Information Nondiscrimination Act of 2008. U.S. Equal Employment Opportunity Commission, <http://www.eeoc.gov/laws/statutes/gina.cfmF $>$ accessed 1 October 2013.

${ }^{54}$ Samantha Besson, 'Enforcing the Child's Right to Know her Origins: Contrasting Approaches under the Convention on the Rights of the Child and the European Convention on Human Rights' (2007) 21 International Journal of Law, Policy and the Family 137.

${ }^{55}$ Katrien Vanfraussen, Ingrid Ponjaert-Kristoffersen, Anne Brewaeys, 'Why do children want to know more about the donor? The experience of youngsters raised in lesbian families' (2003) 24 Journal of Psychosomatic Obstetrics \& Gynecology 31; Ian Craft, Alan Thornhill, 'Would 'all-inclusive' compensation attract more gamete donors to balance their loss of anonymity?' (2005) 10 Reproductive biomedicine online 301.
} 
question is related to the right of third persons not to know, which stems from an individualistic concept of the right to privacy in common law countries where the right to private life is understood as the right to be left alone $^{56}$. The disclosure of patient confidential information may result not only in anxiety, but also in mental health disorders. However, it is of particular importance that genetic information identifies risks of genetic diseases which only manifest in the event of dominant genes, which occur in up to 50 per cent of cases ${ }^{57}$. Thirdly, the disclosure of genetic information does not always have a preventative effect as the current level of medicine does not guarantee a positive influence on the development of a genetic disease (for instance, in the case of Huntington's disease).

Even though in the practice of Lithuanian courts there has not been such a case regarding the violation of a patient's right to a private life by disclosing his genetic information, there were such precedents in the 1990s. In 1995, when deciding whether a doctor should have warned a third person (the patient's daughter) about her mother's inheritable disease, the Florida Supreme Court in the Safer v. Estate of Pack case stated that doctor's duty was only to warn a patient ${ }^{58}$. However, in 1996 the Appeal Court of New Jersey stated that the doctor has a duty to third persons to disclose a patient's genetic information if genetic disease damage may be averted ${ }^{59}$. In soft law sources, inconsistent and contradictory recommendations can be found, ranging from consulting the patient who has genetic research prescribed about the necessity of his family participating ${ }^{60}$, to recommendations based on the outcome of evaluating whether to disclose personal information (for instance, a test if a doctor would agree to disclose his own genetic information) $)^{61}$. Therefore, the expediency of regulating the disclosure of personal genetic information on a legislative level, as discussed in legal doctrine, is clear. It is expected to set a unified standard of information disclosure applicable in all situations and therefore minimise the threat of doctors' liability for disclosing patients' genetic information ${ }^{62}$. On the other hand, the legislator may not foresee and therefore regulate special features of public relations and one-off situations that require the disclosure of a patient's confidential information. Consequently, the Swiss model may be regarded as suitable, as in this model a doctor may refer to a competent institution (for instance, the head doctor of a territorial administrative unit or a national health department) for a patient's consent to disclose his personal information when the patient may not give his consent (for instance, when being unconscious), or when the patient declines to give

\footnotetext{
${ }^{56}$ Samuel Warren, Louis Brandeis, 'The Right to Privacy' Harvard Law Review 5 $<$ http://www.law.louisville.edu/library/collections /brandeis/node/225>, accessed 22 May 2013.

${ }^{57}$ Biologija $<$ http://biologija.kmu.lt/Studentams/MFVI\%20kursas\%20Klin\%20gen/1dalis\%20-klin\%20gen.doc> accessed 16 June 2013.

${ }^{58}$ Pate v. Threlkel, 661 So. 2D 278, 279 (Fla.195).

${ }^{59}$ Safer v. Estate of Pack, 6777A.2d 1188, 1189-90 (N.J. Suoer. Ct.App.Div.1996).

${ }^{60}$ Medical Assotiation <http://www.ama-assn.org//ama/pub/physician-resources/medicalethics/code-medical-ethics/opinion2131.page> accessed 20 June 2013.

${ }^{61}$ ASHG statement. Professional disclosure of familial genetic information. The American Society of Human Genetics Social Issues Subcommittee on Familial Disclosure, http://www.ncbi.nlm.nih.gov/pmc/articles/PMC1376910/pdf/9537923.pdf accessed 20 June 2013.

${ }^{62}$ Suarez (n 36).
} 
it but there is a significant public interest or third party interest to disclose such information ${ }^{63}$.

\section{CONCLUSions}

1. The patients' right to an inviolable private life that is established in the Law on Patients' Rights is an expression of a person's right to privacy in a healthcare relationship. Having established a non-exhaustive list of personal information attributed to health issues, uncertainties regarding both the scope of collection of personal information and the scope of protection of personal information exist.

2. A wide variety of obligations set forth with regard to healthcare services providers (including some obligations which are impossible to fulfil) and complex conditions to disclosing personal information to third parties is an example of exaggerated legal protection.

3. Sufficient legal protection is afforded to the patient's right to a private life by establishing a list of subjects to whom the confidential information may be disclosed without his consent and criteria outlining when such disclosure is permitted.

4. Regulation of a doctor's duty to warn would solve ethical problems of disclosing a patient's confidential information without his consent and would grant legal certainty with regard to the doctor's obligation to protect third parties from damage that can be avoided.

${ }^{63}$ Martin, Guillod (n 18). 